\title{
Metamorfozy historii lokalnej we Lwowie w latach 1869-1939
}

Local history metamorphoses in Lviv in the years 1869-1939

\section{STRESZCZENIE:}

W latach 1869-1939 we Lwowie działało kilkuset historyków. Około 10\% z nich zajmowało się historią regionu oraz należących do niego miast i wsi. Byli wśród nich amatorzy i profesjonaliści, tradycjonaliści i nowatorzy. Niektórzy z nich stali się autorami ciekawych innowacji w historiografii. Przyczynili się do rozwoju, popularyzacji nowatorskich badań lub sposobów prezentowania ich wyników. Miało to miejsce na gruncie: 1) historii społeczno-gospodarczej, 2) historii kobiet, 3) historii historiografii i 4) historii stosowanej (termin ten nie był wtedy znany). Wychodziły one poza kanon uprawianych w tych czasach specjalności i kierunków. Ramę interpretacyjną dla tych tendencji stworzyli Franciszek Bujak, Łucja Charewiczowa i Aleksander Czołowski. Ich dokonania powinny stać się podstawą do przewartościowania wielu obiegowych poglądów na temat historiografii regionalnej i lokalnej. Wskazują też na potrzebę zmodernizowania aparatury pojęciowej $\mathrm{w}$ badaniach nad historią historiografii.

Słowa kluczowe: Lwów, historia regionalna, historia lokalna, historia kobiet, historia historiografii.

Lwów był miastem wyjątkowym dla wszystkich pokoleń historyków zamieszkujących nad Pełtwią. Jego geneza, położenie, znaczenie dziejowe, stosunki narodowościowe i społeczne, formy gospodarowania, oblicze kulturowe, sfery oddziaływania etc. z różnych względów interesowały wielu miejscowych dziejopisów ${ }^{1}$. Historiografia tego ośrodka przeżywała swe „złote czasy" w latach 1869-1939, kiedy to na spolonizowanym Uniwersytecie Lwowskim istniało odrębne studium historyczne. Środowiska

${ }^{1}$ Por. A. Toczek, Środowisko historyków lwowskich w latach 1860-1918, „Prace Komisji Historii Nauki”. Polska Akademia Umiejętności, t. VI, Kraków 2004, s. 123-165. 
skupionego wokół niego dotyczy niniejszy artykuł. Koncentruje się na historykach, którzy na gruncie przeszłości lokalnej zapoczątkowali badania, będące $\mathrm{w}$ przyszłości trwałym czynnikiem wewnętrznych przeobrażeń w historiografii polskiej, a nawet jej wizytówką. Z przyczyn oczywistych artykuł jest daleki od prostego katalogowania wydawnictw dotyczących przeszłości miasta i okolicy. Z tego samego względu abstrahuje od dorobku licznej rzeszy amatorów, piszących z potrzeby serca, głodu wiedzy lub pobudek ideowych ${ }^{2}$.

Za prekursora w sferze badań nad dziejami Lwowa uważa się szesnastowiecznego mieszczanina Jana Alembka ${ }^{3}$. Był on autorem pierwszego drukowanego opisu miasta. Na jego następców trzeba było czekać długo. Ilościowy oraz jakościowy postęp w zakresie rozwoju badań historycznych zaznaczył się dopiero na przełomie XVIII i XIX stulecia. W okresie autonomii Galicji lwowskie środowisko historyczne, obok krakowskiego i warszawskiego, stało się jednym z największych i najbardziej prężnych na ziemiach polskich. Do jego liderów należał Ksawery Liske. Ze względu na swe pograniczne położenie, związki z Austria, tradycje liberalne, wielokulturowość i duże możliwości asymilacyjne, lwowskie środowisko historyczne przyciągało ciekawe osobowości i wykształciło niepowtarzalny charakter ${ }^{4}$.

Ważnym wydarzeniem w życiu naukowym miasta było ukazanie się w 1894 r. Historii Lwowa prof. Fryderyka Papée, która obejmowała nie tylko okres staropolski, ale i XIX stulecie. Autor „skonsumował” w niej doświadczenia naukowe swych kolegów z Warszawy i Krakowa, wzbogacając je własnymi przemyśleniami. Wśród nich zawarł charakterystyczne słowa: „Pielęgnowanie dziejów miejscowych ożywia nie tylko przywiązanie do rodzinnego gniazda, ale jest także potężną podnietą dla uczczenia miłości ojczyzny" . Przyczyniły się one w pewnej mierze do rozwoju zainteresowań historią lokalną. Ciekawe, że znawcy tej problematyki dość nisko ocenili wartość powstających wówczas prac'6. Według Łucji Charewiczowej reprezentatywnych opracowań było wtedy niewiele ${ }^{7}$. Do

\footnotetext{
${ }^{2}$ Por. A. Stępnik, Historia regionalna i lokalna w Polsce 1918-1939. Badania i popularyzacja, Warszawa 1990, s. 41-51.

3 J. Pisulińska, Lwowskie środowisko historyczne w okresie międzywojennym (1918-1939), Rzeszów 2012, s. 14; S. Rachwał, Jan Alenpek i jego "Opis miasta Lwowa" z początku XVII w., „Wschód”, t. VI, Lwów 1930.

${ }^{4}$ A. Toczek, op.cit., s. 123.

${ }^{5}$ F. Papée, Historia miasta Lwowa, Lwów 1894, s. III.

' J. Skoczek, Dotychczasowy stan badań nad historia Lwowa, "Kwartalnik Historyczny", R. XXXIX, 1925, nr 2, s. 336-350 i nadb.; Ł. Charewiczowa, Dziesięciolecie badań nad dziejami miasta Lwowa, „Kwartalnik Historyczny”, R. XLIII, t. II, 1929, s. 115-136.

${ }^{7}$ Ł. Charewiczowa, op.cit., s. 115.
} 
wybitniejszych prac zaliczyła IV tom Pomników dziejowych m. Lwowa, który mimo swego roku wydania (1921) był wynikiem pracy przedwojennej.

Jak obliczył Alfred Toczek, w okresie autonomii Galicji we Lwowie działało ok. 200-330 historyków sensu stricto i sensu largo9. Wśród nich autor doszukał się blisko 260 Polaków, 50 Ukraińców, kilkunastu Niemców i Austriaków oraz kilku Żydów ${ }^{10}$. Więcej niż połowa z nich urodziła się we wschodniej Galicji, a około 10\% stanowili rodowici lwowianie. Blisko połowę tej społeczności tworzyli historycy ze stopniami naukowymi. Największym zainteresowaniem środowiska lwowskiego cieszyły się dziedziny podstawowe, a zwłaszcza historia polityczna I Rzeczypospolitej. W okresie tym dał się zauważyć postęp w dziedzinach wyspecjalizowanych, jak: archeologia, historia literatury, sztuki, filozofii i in. Z opublikowanych w 2013 r. ustaleń A. Toczka wynika, że w okresie autonomicznym historią regionu głównie i wyłącznie zajmowało się 9 (1,7\%) historyków, a częściowo - $17(3,2 \%)$ z nich $^{11}$.

Wzrost zainteresowań przeszłością sprzyjał organizacji zbiorowych warsztatów badań historycznych. Najstarszym i największym z nich było Archiwum Krajowe Akt Grodzkich i Ziemskich (tzw. Bernardyńskie). Poza nim funkcjonowało tu wiele prężnych instytucji i towarzystw naukowych. Najważniejszymi z nich były oczywiście Uniwersytet Lwowski (od 1919 r. Uniwersytet Jana Kazimierza), Towarzystwo Historyczne (od 1924 r. Polskie Towarzystwo Historyczne), Zakład Narodowy im. Ossolińskich, Archiwum Miasta Lwowa, Towarzystwo Miłośników Przeszłości Miasta Lwowa, Towarzystwo Naukowe im. Szewczenki i Żydowskie Koło Naukowe. Alfred Toczek doliczył się 33 takich placówek, które działały w okresie autonomicznym ${ }^{12}$. Niektóre z nich miały statutowy obowiązek wspierania badań lokalnych.

W okresie międzywojnia na terenie Lwowa liczba towarzystw o charakterze społecznym, zawodowym literackim, artystycznym, kulturalnooświatowym oraz naukowym sięgnęła stu. Doczekały się one już charak-

${ }^{8}$ A. Czołowski, F. Jaworski, Księga ławnicza miejska 1441-1448, Lwów 1921.

${ }^{9}$ A. Toczek, Zainteresowania twórcze lwowskiego środowiska historycznego okresu autonomii galicyjskiej w zakresie nauk pomocniczych historii, "Annales Universitatis Paedagogicae Cracoviensis", Folia 104, Studia ad Bibliothecarum Scientiam Pertinentia, t. IX, 2011, s. 142; idem, Środowisko..., s. 126; idem, Lwowskie środowisko historyczne i jego wkład w kulturę ksiażki i prasy (1860-1918), Kraków 2013, s. 31; idem, Historycy amatorzy i popularyzatorzy popularni we Lwowie (1860-1918), [w:] Lwów: Miasto-społeczeństwo-kultura, t. V, Ludzie Krakowa, red. K. Karolczak, Kraków 2005, s. 316-319.

${ }^{10}$ Ibidem .

${ }^{11}$ A. Toczek, Lwowskie środowisko..., s. 206.

12 A. Toczek, Środowisko..., s. 150; por. J. Maternicki, Historiografia polska XX wieku, cz. 1, Lata 1900-1918, Wrocław 1982, s. 193. 
terystyki w dotychczasowej literaturze fachowej. Według obliczeń Joanny Pisulińskiej w latach 1918-1939 działało w ich ramach 372 historyków ${ }^{13}$. Większość z nich (278 osób, tj. 74,7\% ogółu) zajmowała się głównie lub częściowo historią narodową, 112 (32\%) historią powszechną a 75 (20,2\%) głównie lub w sposób znaczący historią regionalną i lokalną ${ }^{14}$.

Historiografia regionalna i lokalna we Lwowie miała dotychczas wielu analityków. Pisali na ten temat szerzej Józef Skoczek ${ }^{15}$, Ł. Charewiczowa ${ }^{16}$, Halina Winnicka ${ }^{17}$, A. Toczek ${ }^{18}$, J. Pisulińska ${ }^{19}$, Jan Wnęk ${ }^{20}{ }^{20}$ Paweł Sierżęga ${ }^{21}$ $i$ in. Nie ma więc głębszego sensu kolejne katalogowanie i systematyzowanie tego dorobku. Przy istniejącym stanie badań można sobie pozwolić na postawienie pytań bardziej szczegółowych. Warto się zastanowić np., o ile lwowska regionalistyka była związana z ogólnymi tendencjami w historiografii polskiej lub ukraińskiej? Czy wnosiła do niej jakieś innowacje? Czy była punktem odniesienia dla innych historyków? Czy wpisywała się $\mathrm{w}$ dokonujące się przeobrażenia kulturowe? Próba odpowiedzi na te pytania jest celem autora niniejszego tekstu.

Analizując dotychczasowe opracowania oraz materiał źródłowy, można zauważyć, że lwowskie środowisko badaczy regionaliów, przynajmniej wśród swych liderów, było grupą poszukującą i starającą się wykorzystywać nowe możliwości poznania historii i opowiadania o niej. Grunt takich postaw tworzyły sprzyjające warunki pracy naukowej w Galicji przed I wojną światową i tuż po niej. Sprawiły one, że w środowisku lwowskim w XX stuleciu nie patrzono na historiografię lokalną jako „młodszą siostrę historii narodowej” czy „bezpieczną przystań dla hobbystów" ${ }^{\prime 22}$. Reprezentujący ją autorzy z reguły sami nie nazywali się regionalistami lecz na ogół badaczami pewnych zagadnień mających lokalne odniesienia. Bez kompleksu prowincji angażowali się oni w nowatorskie

\footnotetext{
${ }^{13}$ J. Pisulińska, op.cit., s. 122.

${ }^{14}$ Ibidem, s. 177.

${ }^{15}$ J. Skoczek, op.cit., s. 336-350.

${ }^{16}$ Ł. Charewiczowa, op.cit., s. 115-136.

${ }^{17}$ H. Winnicka, Lwowskie środowisko historyczne 1918-1939, [w:] Środowiska historyczne II Rzeczypospolitej, red. J. Maternicki, cz. V, Warszawa 1990, s. 121-137.

${ }^{18}$ A. Toczek, Środowisko..., s. 123-165.

${ }^{19}$ J. Pisulińska, op.cit., s. 189-192.

${ }^{20}$ J. Wnęk, Rozwój badań nad historia regionalna Galicji, [w:] Galicja 1772-1918. Problemy
} metodologiczne, stan i potrzeby badań, red. A. Kawalec, W. Wierzbieniec, L. Zaszkilniak, t. 1, Rzeszów 2011, s. 75-99.

${ }^{21}$ P. Sierżęga, Kazimierz Tyszkowski (1894-1940). Z dziejów nauki polskiej w międzywojennym Lwowie, Rzeszów 2011.

${ }^{22}$ Por. A. Stępnik, Trzy modele historii regionalnej w nauczaniu szkolnym, [w:] Historia. Społeczeństwo. Wychowanie, red. J. Maternicki, M. Hoszowska, P. Sierżęga, Rzeszów 2003, s. 61-70. 
wówczas projekty i nurty badań historycznych. Sami też stali się autorami pewnych innowacji w historiografii. Przyczyniły się one do rozwoju badań lub sposobów prezentowania ich wyników w zakresie: 1) nowej historii społeczno-gospodarczej, 2) historii kobiet, 3) historii historiografii i 4) historii stosowanej (to pojęcie było wówczas nieznane). Wychodziły poza kanon uprawianych w tych czasach specjalności i kierunków. Ramę interpretacyjną dla tych tendencji stworzyli Franciszek Bujak, Łucja Charewiczowa i Aleksander Czołowski, ten ostatni mocno związany z życiem Uniwersytetu, lecz niebędący formalnie jego pracownikiem. Przyjrzyjmy się im uważniej.

Franciszek Bujak (1875-1953) był człowiekiem mocno zrośniętym ze Lwowem, choć dużą część życia związał z Krakowem i Warszawą. Urodził się w Galicji (wieś Maszkienice, powiat brzeski). Na uniwersytecie we Lwowie pracował w latach 1921-1941. Tu znalazł oparcie organizacyjne dla swych koncepcji badawczych, najwierniejszych uczniów oraz zostawił niemałą część swego dorobku²3. Dzięki temu uczonemu i jego współpracownikom Uniwersytet Jana Kazimierza stał się jednym z cenionych w Europie ośrodków naukowych. W wielu miejscach kojarzono go ze szkołą Franciszka Bujaka. Badacza tego trudno byłoby nazwać regionalistą w klasycznym rozumieniu tego słowa. Zazwyczaj klasyfikujemy go jako znawcę problematyki społeczno-gospodarczej i organizatora nowych projektów dydaktyczno-naukowych. To on jednak zauważył nowy potencjał tkwiący w źródłach dotyczących mniejszych i większych miejscowości oraz skonstruował nowatorską metodologię ich wykorzystania. Stworzył obiecujące możliwości dla młodych badaczy Galicji i Lwowa.

Osiągnięcia F. Bujaka i jego uczniów były głęboko osadzone w oryginalnej koncepcji nauki historycznej. Dojrzewała ona od początku XX w. do schyłku życia historyka. Przynosiła owoce w lwowskim okresie jego aktywności naukowej, kiedy wokół niego zaczęło się tworzyć środowisko badaczy nowej historii społeczno-gospodarczej. Koncepcja ta wyrastała z ducha pozytywizmu, choć sam autor powoli ewoluował w stronę jej krytyki. Twórca Galicji (Lwów 1908-1910) widział ją jako dziedzinę utylitarną (ściśle związaną z potrzebami społecznymi), humanistyczną (celem nauki jest człowiek), empiryczna, nomotetyczną (zmierzającą do wiedzy zgeneralizowanej) i racjonalistyczną (antyapriorystyczną) ${ }^{24}$. Po względem użyteczności wiedzy historycznej nie przeciwstawiał innym naukom społecznym. Traktował je jako komplementarne w stosunku do siebie.

${ }^{23}$ Bibliografia prac: H. Madurowicz-Urbańska, Bibliografia prac Franciszka Bujaka, F. Bujak, Wybór pism, red. eadem, t. 1, Warszawa 1976, s. 179-216.

${ }^{24}$ Wątek ten rozwija H. Madurowicz-Urbańska, Franciszek Bujak - o nowy kształt historii, [w:] F. Bujak, Wybór..., s. 12-19. 
Uważał, że zadaniem historii powinno być głównie formułowanie podstawy zrozumienia świata, rozwijanie postawy (,instynktu”) społecznej, kształtowanie racjonalnych motywacji w działaniu, poczucia własnej roli i godności w społeczeństwie. Misję realizowania tych funkcji wyznaczał nie tylko historykom i szkołom wszystkich szczebli, ale także ośrodkom prowincjonalnym, muzeom i czasopismom regionalnym ${ }^{25}$.

Zasługi Bujaka dla historiografii regionalnej i lokalnej polegają na unaukowieniu badań w zakresie historii rodzin, wsi, miasteczek i całej Galicji. Swe pierwsze prace odwołujące się do dziejów wsi galicyjskich nazywał monografiami naukowymi, odróżniając je od opisów, w jego opinii dyletanckich, będących dziełem ludzi pozbawionych przygotowania fachowego. Bardzo twórczy, choć nie do końca zrealizowany, był jego pomysł na badanie wsi. Plan ten obejmował oznaczenie i monograficzne opracowanie ok. 60 wsi galicyjskich ${ }^{26}$. Nawiązywał w nim do doświadczeń nauki francuskiej i niemieckiej. W tamtym okresie nazywano je monografiami socjograficznymi. Terminem tym określa się kilka prekursorskich prac Bujaka, „które formalnie były wprawdzie monografiami miejscowości, ale w odróżnieniu od tradycyjnych wydawnictw tego rodzaju tylko w części można je uznać za historyczne, a prawie wcale etnograficzne. Różnił je nie tylko zakres podejmowanych zagadnień (głównie ekonomicznych, w tym z dziedziny stosunków własności, sposobów uprawiania roli, form i źródeł zarobkowania mieszkańców, funkcjonowania kredytu), ale także nowatorskie podejście do metod badawczych i źródeł gromadzenia informacji. Bujak pozyskiwał je nie tylko na drodze klasycznej kwerendy archiwalnej i bibliotecznej, ale przede wszystkim przez badania terenowe i wywiady z mieszkańcami miejscowości" ${ }^{27}$. W tym duchu na początku XX stulecia, a więc jeszcze w okresie pobytu historyka w Krakowie, powstały monografie wsi i miasteczek galicyjskich: Maszkienic, Żmiącej i Limanowej ${ }^{28}$. Były one studiami z zakresu kultury materialnej, zawierały

${ }^{25}$ Por. F. Bujak, O nauczaniu historii, zwłaszcza w szkołach zawodowych, [w:] Pamiętnik V Powszechnego Zjazdu Historyków Polskich w Warszawie 28 XI-4 XII r., Lwów 1930, s. 625-632 i nadb.; idem, O pracy naukowej na prowincji nad zagadnieniami gospodarczymi, „Nauka Polska", t. IV, 1923, s. 237-243; idem, Dział historii gospodarczej, [w:] Muzea regionalne ich cele i zadania, książka zbiorowa, Warszawa 1928, s. 204-217.

${ }^{26}$ J. Wnęk, op.cit., s. 84 .

${ }^{27}$ Z. Budzyński, Franciszek Bujak (1875-1953), [w:] Złota księga historiografii lwowskiej XIX $i$ XX wieku, red. J. Maternicki przy współpracy L. Zaszkilniaka, [t. I], Rzeszów 2007, s. 426

${ }^{28}$ F. Bujak, Maszkienice. Wieś powiatu brzeskiego. Stosunki gospodarcze i społeczne, „Rozprawy Akademii Umiejętności. Wydział Historyczno-Filozoficzny", seria 2, t. XVI, 1901, s. 76-184 i nadb.; idem, Żmiaca. Wieś powiatu limanowskiego. Stosunki gospodarcze i społeczne, Kraków 1903; idem, Limanowa. Miasteczko powiatowe w zachodniej Galicyi. Stan społeczny i gospodarczy, Kraków 1902. 
dokładny rejestr codziennych zajęć mieszkańców oraz ich opłacalności. Stanowiły grunt do wskazań czy działań praktycznych. Podsumowaniem doświadczeń na polu socjografii było studium Wieś zachodniogalicyjska u schytku XIX $w .{ }^{29}$, a potem dwutomowa monografia Galicja ${ }^{30}$. „Opis gospodarczy to nie naiwne i zbyteczne powtarzanie rzeczy powszechnie znanych, ale pożyteczne zbieranie i uprzystępnianie materiału naukowego" - pisał ${ }^{31}$. Uważał, że historyk-uczony powinien zbliżać się do modelu wypracowanego na gruncie przyrodoznawstwa. Powszechny dotychczas idiografizm powinien być zstąpiony zasadą reprezentacji i integralności ujęcia całej jednostki osadniczej. Później koncepcja ujęcia socjograficznego ustąpiła koncepcji monografii historycznej (z wykorzystaniem mikroanalizy) małych układów społecznych.

W rozumowaniu Bujaka badania lokalne powinny poprzedzić nową syntezę dziejów Polski. W r. 1938 pisał: „Poznanie i stwierdzenie charakteru regionu, czyli tworzenie jego syntezy, wymaga nie tylko szczegółowego badania jego fizjografii, antropogeografii i ludoznawstwa [...] jak i piękna dzieł myśli i ręki jego mieszkańców [...]. Aby to badanie i poznanie było integralne, spełniało swoje zadanie, nie może się ono ograniczać do stosunków dzisiejszych, ale musi się rozciągnąć na całą przestrzeń regionu"32. Swego adwersarza miał Bujak w Janie Rutkowskim z Poznania, który uważał, że małą przestrzeń należy badać nie integralnie, lecz problemowo. Jest to jednak zagadnienie wykraczające poza ramy niniejszego artykułu ${ }^{33}$.

W latach trzydziestych XX w. aktywność naukowo-badawcza F. Bujaka osłabła. Nie ucierpiał jednak jego autorytet jako mistrza w środowisku lwowskim. Historyk poświęcił się wówczas pracy na uniwersytecie, działalności społeczno-politycznej i konstruowaniu wielkich projektów badawczych skupiających młodszych pracowników i studentów. Zalecał im „opracowywanie tematów dotyczących dziejów Lwowa, co w dużej mierze było uwarunkowane dostępnością źródeł dotyczących tej problematyki" ${ }^{\prime 34}$. Nie bez znaczenia były jego zobowiązania wobec miasta, o którym mowa. Bujak był niestrudzonym organizatorem ruchu wydawniczego. Do jego sukcesów należy zaliczyć uruchomienie w 1925 r. nowej

${ }^{29}$ Idem, Wieś zachodniogalicyjska u schyłku XIX w., "Przegląd Prawa i Administracji”, R. XXIX, 1904, s. 365-385, 418-433, 502-523 i nadb.

${ }^{30}$ Idem, Galicja, t. I-II, Lwów 1908-1910.

${ }^{31}$ Idem, O pracy naukowej..., s. 241.

${ }^{32}$ Idem, List do Redakcji "Gronie", Żywiec 1938.

${ }^{33}$ Por. D. Konieczka-Śliwińska, Region i regionalizm w badaniach historycznych, [w:] "Duża i mała ojczyzna" w świadomości historycznej, źródłach i edukacji, red. B. Burda, M. Szymczak, Zielona Góra 2010, s. 17.

${ }^{34}$ J. Pisulińska, op.cit., s. 190-191. 
serii pn. „Badania z Dziejów Społecznych i Gospodarczych”. Miała ona na celu ustalanie, rejestrowanie źródeł, które stać się miały w przyszłości podstawą nowej syntezy ${ }^{35}$. Podobny cel przyświecał uruchomieniu w $1926 \mathrm{r}$. serii „Prac Społeczno-Gospodarczych” publikowanych w Bibliotece Puławskiej. Działalność organizacyjno-wydawnicza przyniosła też efekt w postaci „Roczników Dziejów Społeczno-Gospodarczych” (wydawanych od 1931 r. wraz z J. Rutkowskim) oraz wydawanej od 1932 r „Biblioteki Dziejów i Kultury Wsi". Dobrze zapowiadającym się konceptem był pomysł na nową historię Lwowa, jednak nie doczekał się on realizacji ${ }^{36}$.

Można zaryzykować twierdzenie, że w okresie międzywojnia działania praktyczne zaczęły wyprzedzać refleksję teoretyczną tego uczonego. Mimo to, na drodze w pewnym stopniu eksperymentalnej, w latach dwudziestych ukształtował się wizerunek lwowskiej szkoły historii społeczno-gospodarczej, wyróżniającej się określonym profilem badawczym, oryginalną metodologią i narzędziami badawczymi. Stawiała ona na nowe rodzaje źródeł masowych, niedocenianych przez ówczesną historiografię. Znaczną rolę w rozwoju dziejowym przypisywała ekonomii. Bujak wprawdzie rozumiał, że stosunki ekonomiczne nie wypełniają głównej treści życia narodów i ludzkości, twierdził, że są jednak ich bardzo istotnym elementem ${ }^{37}$. Uważał, że rzutują one szczególnie na kondycję mniejszych wspólnot jak i pojedynczych ludzi i stanowią ważną motywację codziennych działań. Stąd brała się pochwała metody statystycznej, której Bujak zawsze bronił. Postulował nawet przejście od metod statystyki opisowej do metod statystyki historycznej, uwzględniające elementy rachunku prawdopodobieństwa. Sądził, że w ten sposób można mierzyć pewne zjawiska historyczne, a zwłaszcza czas ich trwania i zasięg oddziaływania. Dzięki temu możliwe jest konstruowanie bardziej ścisłych wniosków i odejście od spekulacji. Twierdził, że od ekonomii i metod statystycznych dystansują się ci, którzy ich nie rozumieją. Pod koniec lat dwudziestych Bujak zaczął podkreślać związek nauki historycznej z socjologią. „Przygodne informacje od wypadku do wypadku już nie wystarczają - pisał

${ }^{35}$ Por. S. Inglot, Franciszek Bujak. Działalność naukowa i pedagogiczna. Referat wygłoszony na posiedzeniu żałobnym Wydziału Historyczno-Filozoficznego dnia 6 maja 1953 roku, „Sprawozdania Wrocławskiego Towarzystwa Naukowego", [t.] 8, 1953, dodatek 3, s. 12-13.

${ }^{36} \mathrm{H}$. Madurowicz-Urbańska, Stan badań nad historia Lwowa w latach 1772-1918, „,Rocznik Naukowo Dydaktyczny" Wyższa Szkoła Pedagogiczna im. Komisji Edukacji Narodowej w Krakowie. Prace Historyczne nr XIII, Studia z dziejów Małopolski w XIX i XX wieku, red. L. Mroczko, Kraków 1992, s. 39.

${ }^{37}$ A.F. Grabski, Franciszek Bujak i historia gospodarcza (uwagi o metodologicznych pogladach uczonego), „Historyka. Studia Metodologiczne”, t. IX, 1979, s. 113; por. też T. Pawelec, Trzy wizje dziejów - F. Bujak, M. Handelsman, J. Rutkowski, [w:] Środowiska historyczne II Rzeczypospolitej, cz. V, red. J. Maternicki, Warszawa 1990, s. 170. 
- potrzeba posiadać cały system tych pojęć. Bez nich stanowisko naukowe historii jest bardzo słabe, bo one stanowią jej fundament" ${ }^{\prime 38}$. Swej konsekwencji dowiódł, tworząc i realizując w latach trzydziestych własny program akademicki na UJK, który przybrał charakter studium pomocniczego dla studentów historii. Obejmował on elementy geografii historycznej z kartografia, antropogeografii, prawa politycznego, ekonomii społecznej, statystyki, demografii, socjologii ogólnej oraz podstaw analizy artystycznej i dziejów kultury. Poglądy naukowe Bujaka były inspiracją dla innych historyków zajmujących się zagadnieniami lokalnymi.

Sam Bujak przyszłość badań historycznych widział w pracy zespołowej. „Praca młodych »bujakowców« organizowana była według sprawdzonego schematu. Pierwszy tom cyklu przynosił koncepcję opracowania, którą naśladowano w kolejnych studiach. Walawender torował droge swoim kolegom przygotowującym następne roczniki klęsk elementarnych, Hoszowski tym seminarzystom, którzy zajmowali się cenami. [...] Bujak kładł nacisk przede wszystkim na pilne wyszukiwanie i rejestrowanie źródeł, na sumienne stwierdzanie i porządkowanie faktów oraz na ich sumowanie, czyli wstępne opracowanie. Synteza i konstruowanie obrazu przeszłości miały z natury leżeć na dalszym planie, bo uważano za właściwe, aby początkujący uczniowie pozostawiali syntezę bardziej doświadczonym badaczom". Bujak zapewniał swoim uczniom druk wszystkich zasługujących na to prac"39.

Efektem tak organizowanej pracy był cykl publikacji dotyczący cen Lwowa i innych miejscowości. Był on znakiem rozpoznawczym szkoły Bujaka. W zamierzeniu inicjatora tego pomysłu badanie cen miało być „środkiem pomocniczym” dla potrzeb historyków społeczno-gospodarczych $^{40}$. Pierwszym wydawnictwem z tego cyklu były Ceny we Lwowie Stanisława Hoszowskiego, w których autor podał notowania kursowe w latach 1501-1914 ${ }^{41}$. W przedmowie do tego tomu Bujak napisał: „Studia nad cenami są niewątpliwie pierwszorzędnym zadaniem historii gospodarczej i stanowią jej podwalinę. Stan i ruch cen jest kamieniem probierczym dla wszystkich badań historyczno-gospodarczych; stanowi realną

${ }^{38}$ F. Bujak, Reforma studiów historycznych na Uniwersytecie z punktu widzenia przygotowania do zawodu nauczycielskiego, "Wiadomości Historyczno-Dydaktyczne”, R. I, 1933, z. 1, s. 12.

${ }^{39}$ A. Janeczek, Franciszek Bujak: historyk w nurcie życia, [w:] F. Bujak, Studya nad osadnictwem Małopolski, posł. A. Janeczek, Poznań 2001, s. 226.

${ }^{40}$ S. Hoszowski, Klęski elementarne $i$ ceny w działalności Profesora Franciszka Bujaka, „Sprawozdania Wrocławskiego Towarzystwa Naukowego", 29, 1974, seria A, dodatek, s. 129 [19]. Badania nad cenami we Lwowie rozpoczęły się w 1924 r.

${ }^{41}$ Idem, Ceny we Lwowie w XVI i XVII wieku, przedm. F. Bujak, Lwów 1928, Badania z Dziejów Społecznych i Gospodarczych, z. 4. 
podstawę dla szeregu zjawisk gospodarczych, ożywia je i uzmysławia, ułatwiając nam wytworzenie sobie wyobrażenia o ich wadze, rozmiarach i możliwych skutkach"42. Uważał, że opracowania te mogą służyć przedstawicielom wielu innych dyscyplin naukowych. W ciągu 15 lat powstało 11 monografii (opartych na podobnych założeniach metodycznych i edytorskich) poświęconych tej problematyce. Obejmowały one materiał źródłowy od początku XV do początku XIX stulecia. Lwowska monografia Hoszowskiego była punktem odniesienia dla pozostałych autorów. Inaczej była skonstruowana praca Mennica lwowska w latach 1656-1657 Rudolfa Mękickiego z 1932 r. ${ }^{43}$ Miała inny charakter, ale była inspirowana dorobkiem „bujakowców"44.

$\mathrm{W}$ środowisku lwowskim $\mathrm{z}$ dużym zainteresowaniem traktowano też klęski elementarne, które wpisywano w życie gospodarcze. Oceniając potrzeby badawcze $\mathrm{w}$ tym zakresie, Bujak wymieniał na pierwszym miejscu pożary, powodzie, susze i epidemie ${ }^{45}$. W tym celu powstała Kronika klęsk elementarnych, w ramach której opublikowano cztery tomy ${ }^{46}$. Dość krytyczny wobec „szkoły bujakowskiej” Zdzisław Budzyński uważa, że rzeczywiście były one wizy tówką tego środowiska ${ }^{47}$. Problematyką tą interesowali się najlepsi uczniowie Bujaka: S. Hoszowski i Stefan Inglot $^{48}$. Pewnym uzupełnieniem tej serii były Klęski zaraz w dawnym Lwowie Ł. Charewiczowej (1930).

Innym pomysłem Bujaka, z okresu lwowskiego był projekt przygotowania cyklu monografii przedsiębiorstw przemysłowych. Nie spotkał się on $\mathrm{z}$ odzewem $\mathrm{w}$ tym środowisku. Na marginesie projektu powstało kilka monografii ziemskich jednostek majątkowych, w innych jednak ośrodkach akademickich ${ }^{49}$.

\footnotetext{
${ }^{42}$ F. Bujak, Przedmowa, [w:] ibidem, s. III.

${ }^{43}$ R. Mękicki, Mennica lwowska w latach 1656-1657, Lwów 1932. Biblioteka Lwowska, t. XXXI.

${ }^{44}$ Por. H. Winnicka, op.cit., s. 130.

${ }^{45}$ F. Bujak, Uwagi o potrzebach historii gospodarczej, "Nauka Polska. Jej Organizacja i Rozwój", t. I, 1918, s. 275-286.

${ }^{46}$ A. Walawender, Badanie klęsk elementarnych. Metoda i znaczenie, Lwów 1931; idem, Kronika klęsk elementarnych w Polsce i krajach sasiednich w latach 1430-1586, Lwów 1932, Badania z Dziejów Społecznych i Gospodarczych, z. 6.

${ }^{47}$ Z. Budzyński, Szkoła historii społeczno-gospodarczej Franciszka Bujaka na Uniwersytecie Jana Kazimierza we Lwowie, [w:] Wielokulturowe środowisko historyczne Lwowa w XIX i XX w., t. II, red. J. Maternicki, L. Zaszkilniak, Rzeszów 2004, s. 323.

${ }^{48}$ Por. S. Hoszowski, Ceny we Lwowie w XVI i XVII wieku...; idem, Ceny we Lwowie w latach 1701-1914, Lwów 1934, Badania z Dziejów Społecznych i Gospodarczych, z. 13; idem, Ekonomiczny rozwój Lwowa w latach 1772-1914, Lwów 1935. S. Inglot badał ceny na Pomorzu i Dolnym Śląsku. Po II wojnie św. obaj zostali profesorami historii gospodarczej. Kontynuowali tradycje szkoły Bujaka.
}

${ }^{49}$ Z. Budzyński, Szkoła..., s. 322. 
Ocenie dorobku F. Bujaka i jego szkoły towarzyszą różne opinie, rozciągające się od zachwytu do poważnej krytyki. Bujak i jego szkoła to dla Heleny Madurowicz-Urbańskiej kwiat ówczesnej nauki polskiej. Witold Kula uważał ich publikacje za usystematyzowany, ale jednak tylko surowy materiał źródłowy. Zdzisław Budzyński metodologiczne pomysły Bujaka uznał za "mało oryginalne i zborne”, gdyż w tym przypadku „rozwój praktyki badań historyczno-gospodarczych wyraźnie wyprzedzał kładzenie fundamentów teoretycznych" ${ }^{50}$. Odkryciom źródłowym nie zawsze towarzyszyła wystarczająco pogłębiona warstwa interpretacyjna. Historyk rzeszowski za kontrowersyjne uznał przyjęcie przez lwowian „przelicznika kruszcowego" ${ }^{\prime 51}$.

Nie zmienia to faktu, że Bujak stworzył nową ramę interpretacyjną dla wielu zagadnień odnoszących się do Galicji i samego Lwowa. Żaden z późniejszych historyków nie mógł przejść obok jego osiągnięć obojętnie.

Ważną postacią wśród lwowskich badaczy regionaliów była Ł. Charewiczowa (1897-1943). Lwów nie był jej miastem rodzinnym, ale związała z nim właściwie całe życie zawodowe i naukowe. Do 1930 r. pracowała jako asystentka na uniwersytecie, od 1931 r. jako kustosz w Muzeum Miasta Lwowa. Była uczennicą i asystentką Jana Ptaśnika. Krótko (w roku akademickim 1922/23) uczestniczyła w seminarium Historii Społecznej i Gospodarczej F. Bujaka. Często powoływała się na poglądy naukowe obu profesorów. Obydwaj mistrzowie także cenili osiągnięcia swojej uczennicy. Przypomnijmy, że Bujak był wnioskodawcą wnoszącym, by w 1937 r. przyjąć habilitację młodej badaczki bez potrzeby wygłaszania przez nią wykładu, a Ptaśnik w „Kwartalniku Historycznym” ogłosił jej Dzieje Złoczowa za wzór monografii miejskiej ${ }^{52}$.

Łucja Charewiczowa poświęciła Lwowu większość swoich prac, nierzadko pionierskich. Wszystkie z nich umiała zaprezentować w sposób fachowy, lecz zarazem przystępny. $W$ okresie międzywojennym zaliczano ją do czołówki polskich „historyków-urbanistów" ${ }^{53}$. W środowisku tym miasta traktowano jako samodzielny przedmiot badań, przy czym zauważano fakt, że „W Polsce XVII i XVIII stulecia miasta ulegały agraryzacji, a w XIX wieku procesy zaczęły się odwracać, w wieku XX zaś całkowicie

\footnotetext{
${ }^{50}$ Idem, Franciszek Bujak (1875-1953), [w:] Złota księga historiografii..., s. 438.

${ }^{51}$ Bujak „uznawał cenę nominalną oznaczonego towaru lub usługi (płaca) za pozorną i względna, przyjął więc jako podstawę wskaźnika cen jej równoważnik przeliczany w gramach kruszcu [...] mimo krytycznego stanowiska J. Rutkowskiego, który już w 1935 r. postulował wprowadzenie, równoległego do indeksu kruszcowego złotego i srebrnego, indeksu nominalnego". Cyt. za Z. Budzyński, Szkoła..., s. 323-324.

${ }^{52}$ „Kwartalnik Historyczny” R. LXIII, 1929, s. 589.

${ }^{53}$ M. Friedberg, Łucja Charewiczowa (1897-1943), „Kwartalnik Historyczny” R. LXVI, 1939-1945, z. 3-4, s. 436-440.
} 
się odwróciły" ${ }^{54}$. To nie wieś, jak kiedyś, „podbijała” miasto, to miasto „podbijało" wieśs ${ }^{5}$.

W sumie Charewiczowa napisała ok. 100 większych i mniejszych prac. Koncentrowały się one wokół przeszłości Lwowa, a zwłaszcza jego społeczeństwa i kultury materialnej. Miasto to przedstawiała jako strukturę społeczna, żywą, zmienną i zróżnicowana, kumulującą w sobie wpływy Wschodu, Zachodu i Południa (szlak czarnomorsko-bałtycki) ${ }^{56}$. Swe zainteresowania tą tematyką wyniosła z seminarium J. Ptaśnika. Zwykł on mawiać swoim uczniom, że badania historyczne trzeba zaczynać od terytorium, z którym jest się osobiście związanym.

Z interesującej nas perspektywy Łucję Charewiczową można uznać za jedną z orędowniczek i prekursorek badań nad dziejami kobiet ${ }^{57}$. Problematyka kobieca pojawia się właściwie w większości prac tej autorki. Nawiązywała do niej analizując obyczaje, zagadnienie pracy, zarobkowania, zajęcia ludności jako źródła rozwoju gospodarczego. Dostrzegała pozycję kobiet w cechach rzemieślniczych.

W latach trzydziestych Charewiczowa zaczęła interesować się historią kobiet w sposób systematyczny. Doszła do wniosku, że jest to problematyka z wielką przyszłościa, potrzebna zarówno samym kobietom, jak i modernizującemu się społeczeństwu. Wierzyła, że jej ustalenia pomogą zrozumieć pojęcie „kobiety nowoczesnej” i pokazać długą jej drogę do emancypacji. Zainteresowania te ukształtowały się zapewne na marginesie badań nad miastami i kulturą. „Możliwe - pisze Alicja Kusiak - że inspiracje feministyczne wiązały się z okresem paryskich studiów. Najbardziej jednak prawdopodobnym wytłumaczeniem wydaje się być społeczne zaangażowanie Charewiczowej w działalność organizacji kobiecych" ${ }^{\prime 58}$. Trudno powiedzieć, które z tych motywacji były najsilniejsze.

${ }^{54}$ A Chwalba, O nowy ksztatt historycznych badań regionalnych - uwagi do tekstu Roberta Traby, [w:] O nowy model historycznych badań regionalnych, red. K. A. Makowski, Poznań 2007, s. 89.

${ }^{55}$ Ibidem.

${ }^{56}$ Por. H. Madurowicz-Urbańska, Łucja Charewiczowa i jej Lwów, [w:] Kraków-Małopolska w Europie Środka. Studia ku czci profesora Jan M. Małeckiego w siedemdziesiąta rocznice urodzin, red. K. Broński, J. Purchla, J. Szpak, Kraków 1996, s. 190.

${ }^{57}$ J. Pisulińska, op.cit., s. 55; por. A. Kusiak, Łucja Charewiczowa-inicjatorka badań nad przeszłościa kobiet polskich, [w:] Kobieta i kultura. Kobiety wśród twórców kultury intelektualnej $i$ artystycznej $w$ dobie rozbiorów $i$ w niepodległym państwie polskim, red. A. Żarnowska, A. Szwarc, t. IV, Warszawa 1996, s. 99-103. Niektórzy znawcy tej problematyki uważaja że historia kobiet ukształtowała się w Polsce dopiero na przełomie lat 80. i 90. XX w., por. D. Kałwa, Historia kobiet versus studia gender, [w:] Historia - dziś. Teoretyczne problemy wiedzy o przeszłości, red. E. Domańska, R. Stobiecki, T. Wiślicz, Kraków 2014, s. 118.

${ }^{58}$ A. Kusiak, op.cit., s. 101. 
Wiemy na pewno, że na VII Międzynarodowym Kongresie Nauk Historycznych w Warszawie (1933) zaprezentowała referat pt. Est-il fondé d'écrire une historie spéciale de la femme (Czy należy napisać odrębna historię kobiet?). Trudno go uznać za artykuł programowy. Autorka nie formułowała w nim konkretnych dyrektyw badawczych. Wyrażała jedynie przekonanie, że historię kobiet da się napisać i zastanawiała się nad wyborem źródeł i rodzaju narracji. Chciała zmienić obraz, w którym eksponowane były tylko „rozrodcza rola kobiety”, błahostki ze świata mody i przepisów kulinarnych. „Aż do tego momentu - pisała w swym referacie - eksponowano wyłącznie cechy kobiety w wąskich ramach życia rodzinnego, umniejszając tym samym jej człowieczeństwo, jej instynkt społeczny. Praca dla rodziny jest obowiązkiem wrodzonym i naturalnym dla obu płci [...]. Tym, czego trzeba szukać i podkreślać, są wartości elementów istotnie esencjonalnie kobiecych i ich wpływ na życie społeczne" ${ }^{\prime \prime 5}$. Dorota Malczewska-Pawelec po analizie różnych wypowiedzi Charewiczowej uznała, że „historia kobiet w ujęciu Charewiczowej to osadzone na szerokim tle społeczno-kulturowo-gospodarczym danej epoki pogłębione źródłowo studia, które ukazywałyby kobiety z przeszłości »W całej rzeczywistości życia ich płci, sposobu myślenia i bytu«. Koncentrować się miały zwłaszcza na ich wychowaniu, edukacji, pozycjach społecznych, obszarach aktywności, wyznawanych wartościach. Ważnym ich elementem powinno być odsłanianie indywidualnych rysów poszczególnych bohaterek, a także przybliżanie sfery ich przeżyć, doznań i emocji. Historia kobiet w wersji Charewiczowej miała unikać idealizowania obiektu badań. Postacie kobiece należało ukazywać wielostronnie i wielowymiarowo. Słabości i wady były równie istotne, jak zalety, osiągnięcia czy sukcesy"60. W ich badaniu pomocna miała być analiza psychologiczna oraz obserwacja życia zbiorowego i indywidualnego ${ }^{61}$. Można w tym upatrywać inspiracji myślą historyczną F. Bujaka.

W orbicie zainteresowań Charewiczowej znalazły się m.in. takie zagadnienia, jak: rola kobiety $\mathrm{w}$ rodzinie, handlu, rzemiośle, mecenacie i kulturze artystycznej Lwowa. Kobiety prezentowane były jako wytwór epoki. W taki sposób autorka próbowała konstruować biografie bohaterek swoich opracowań. Na ogół były to zwykłe mieszczanki, żyjące daleko od

${ }^{59}$ Ł. Charewiczowa, Est-il fonde d'ecrire une histoire specjale de la femmme? Warszawa 1933, s. 1-2, wolne tłumaczenie A. Kusiak, op.cit., s. 102.

${ }^{60}$ D. Malczewska-Pawelec, Łucja Charewiczowa (1897-1943), [w:] Złota ksiega historiografii..., t. II, Rzeszów 2014, s. 528; eadem, Łucja Charewiczowa jako badaczka i propagatorka historii regionalnej, „Wieki Stare i Nowe”, w druku.

${ }^{61}$ Ł. Charewiczowa, Est-il fondé d'écrire une historie spéciale de la femme, Warszawa 1933, s. 4. 
świata wielkich wydarzeń, zasługujące dopiero na odkrycie przez historię. W 1935 r. ukazały się prace Mieszczka lwowska XVI w. Zofia Hanlowa ${ }^{62}$ i Z przeszłości Lwowianek ${ }^{63}$. Problematykę tę badaczka popularyzowała też na łamach prasy. W rękopisie pozostała duża praca dotycząca historii kobiet. Zaginęła ona podczas wojny, kiedy jej autorka trafiła do Auschwitz. Pozostał po niej jedynie popularny szkic pt. Kobieta w dawnej Polsce do okresu rozbiorów (1938), który dotyczył tylko ziemianek, zaś marginalizował chłopki i mieszczanki. Ciekawą broszurą (wydaną pod pseudonimem C. Mikułowska) był Ukraiński ruch kobiecy ${ }^{64}$. Niektórzy traktują te prace jako początki historiografii kobiecej. Publikacja Kobieta w dawnej Polsce do okresu rozbiorów $w^{65}$ zainaugurowała serię wydawniczą Kultura polska i obca pod redakcją Kazimierza Hartleba. Autorka przedstawiła w niej w sposób barwny dzieje kobiet do XVIII w. w trzech płaszczyznach: życia obyczajowego, społecznego i umysłowego. Wskazała na ich bierność, co tłumaczyła uwarunkowaniami kulturowymi. Niektórzy współcześni badacze historiografii upatrują $\mathrm{w}$ tym podejściu śladów perspektywy antropologicznej ${ }^{66}$.

Odrębną kartę w dorobku Charewiczowej stanowi praca Historiografia i miłośnictwo Lwowa ${ }^{67}$. Lwowska badaczka zajęła się tu autorami i publikacjami odnoszącymi się do dziejów miasta (od XVII do XX w.). Żadne z polskich miast nie mogło się wówczas poszczycić takim opracowaniem. Jak słusznie zauważyła D. Malczewska-Pawelec, „rozprawa ta wpisuje się na listę pierwszych prac budujących nową subdyscyplinę badań historycznych - historię historiografii" ${ }^{68}$. Marian Friedberg napisał o niej: „Piękna ta książka, jedyna tego rodzaju w literaturze miast dawnej Polski, z naukową dokładnościa, a zarazem owianym poezją sentymentem wylicza długie pokolenia historiografów i piewców przeszłości Lwowa, od w. XVII aż po czasy ostatnie" ${ }^{\prime \prime 9}$. Intencją autorki było stworzenie obrazu, który ukazywałby kierunki badań i główne postacie, ważne dla historiografii Lwowa. Autorzy ci według Charewiczowej byli „wytworami atmosfery historycznej Lwowa”, który mocno wpływał na wrażliwość i postawy mieszkańców oraz ludzi, którzy się z nim zetknęli. Co ciekawe, uznała, że osobą, która wyprowadziła historiografię lwowską spoza opłot-

${ }^{62}$ Eadem, Mieszczka lwowska XVI w. Zofia Hanlowa, „Ziemia Czerwieńska” 1935, z. 1, s. 26-66 i nadb.

${ }^{63}$ Eadem, Z przeszłości Lwowianek, Warszawa 1935.

${ }^{64}$ C. Mikułowska [Ł. Charewiczowa], Ukraiński ruch kobiecy, Lwów 1937.

${ }^{65}$ Ł. Charewiczowa, Kobieta w dawnej Polsce do okresu rozbiorów, Lwów 1938.

${ }^{66}$ D. Malczewska Pawelec, Łucja Charewiczowa jako....

${ }^{67}$ Ł. Charewiczowa, Historiografia i miłośnictwo Lwowa, Lwów 1938.

${ }^{68}$ D. Malczewska-Pawelec, Łucja Charewiczowa (1897-1943)..., s. 526.

${ }^{69}$ M. Friedberg, op.cit., s. 436. 
ków dyletantyzmu był Ksawery Liske ${ }^{70}$. To on uczynił Lwów ośrodkiem naukowym.

W tym nurcie mieścił się też zamieszczony w 1929 r. w „Kwartalniku Historycznym" tekst tej samej autorki pt. Dziesięciolecie badań nad dziejami Lwowa, który był próbą bilansu dorobku historiografii lokalnej w latach 1919-192971. Stanowił on też apel do władz miasta o wspieranie tego typu badań. W pracy tej młoda badaczka zwracała uwagę na niedostatek naukowych opracowań i dominujący w tej dziedzinie dyletantyzm. Wyrażała przekonanie, że $\mathrm{w}$ popularyzacji regionu konieczna też jest znajomość reguł naukowych. Dorobek lwowskich dziejopisarzy pokazywała na szerszym tle, które zostało zarysowane w krytycznym referacie Stan badań nad dziejami miast polskich ${ }^{72}$. Podniosła w nim potrzebę rozwijania badań lokalnych i zainteresowania się przeszłością takich stanów społecznych, jak rzemieślnicy i kupcy. O dużej wrażliwości historiograficznej Charewiczowej świadczyć mogą też prace: Dzieje miast w polskiej literaturze historiograficznej oraz Stan badań nad dziejami miast Polski, jak również artykuł Przeglad nowszych monografii miast polskich. Ukazały się one w „Kwartalniku Historycznym", a Lwów zajmował w nich poczesne miejsce. Prace te korespondowały z publikacją J. Skoczka, choć nie wchodziły z nią w polemikę $e^{73}$.

Główną domeną zainteresowań Charewiczowej była historia miast, w szczególności Lwowa ${ }^{74}$. Dotyczyła ona szerokiego przedziału czasowego: od XV do XX w. W latach 1924-1938 opublikowała 28 prac dotykających tej problematyki. Ok. 70\% z nich odnosiło się do Lwowa. W tej dziedzinie nie była prekursorka, ale, jak pisał J. Ptaśnik, jeśli w dziejach urbanistyki polskiej miała „swe dobre zasłużone imię, to przez ostatnie publikacje wysunęła się na czoło badaczy w tej gałęzi nauk historycznych"75.

W czołówce badaczy dziejów Galicji i Lwowa warto też zauważyć postać ciekawego historyka, muzealnika, archiwisty i konserwatora zabytków Aleksandra Czołowskiego (1865-1944) ${ }^{76}$. Nie był on akademi-

${ }^{70}$ Por. A. Toczek, Środowisko..., s. 123-165.

${ }^{71}$ Ł. Charewiczowa, Dziesięciolecie badań..., s. 115-136.

72 "Przegląd Historyczny”, t. 27, 1928, s. 139-152.

${ }^{73}$ J. Skoczek, op.cit.

${ }^{74}$ Por. J. Suchumiel, Łucja Charewiczowa (1897-1943). Życie i dzieło, Częstochowa 2001.

${ }^{75}$ J. Ptaśnik, [rec.] Charewiczowa Łucja” "Lwowskie organizacje zawodowe za czasów Polski przedrozbiorowej", Lwów 1929, s. 1-191, i Dzieje miasta Złoczowa", Złoczów 1929, s. 1-220, „Kwartalnik Historyczny”, R. XLIII, 1929, t. 1, s. 587-589.

${ }^{76}$ I. Zima, Aleksander Czołowski 1865-1944. Luminarz lwowskiej kultury, Gdynia 2011; bibliografia prac w E. Laszak, Działalność naukowa Aleksandra Czołowskiego (1865-1944), Łódź 2004, s. 149-161. 
kiem (przez co został nieco zapomniany), ale pozostawał z uniwersytetem i jego pracownikami w rozlicznych relacjach. Ograniczenia wydawnicze nie pozwalają szerzej się do nich odnieść. Zasygnalizujmy więc tylko, że pasje zawodowe i prywatne Czołowskiego ukształtowały jego wyjątkową wrażliwość, sposób myślenia o historii, a także charakterystyczny sposób opowiadania o niej. Szły za tym pomysły na nowe formy popularyzacji dziejów w postaci książek, albumów, przewodników, artykułów, wystaw, obchodów, odczytów, wykładów, a nawet audycji radiowych. Dziś moglibyśmy traktować je jako prekursorskie formy public history czy „historii stosowanej”, polegające na "czytaniu krajobrazu kulturowego" łączącego kontekst poznawczy, edukacyjny i komercyjny. Jego popularny Lwów w obrazach był odpowiednikiem dzisiejszych pocket books ${ }^{77}$. Składał się z krótkich ciekawostek skonstruowanych według, dziś powiedzielibyśmy, klucza lwowskich „miejsc pamięci”. Nowatorstwo Czołowskiego w środowisku lwowskim polegało też na tym, że zaczął on traktować dzieła sztuki i zabytki jako istotne źródła historyczne i jednocześnie środki perswazji. Prace tego historyka wyróżniały się innowacyjną narracją odkrywająca przeszłość w teraźniejszości, bogatą szatą graficzna, nietypowym formatem jego publikacji. Czołowski nie zdobył się nigdy na pełną syntezę dziejów Lwowa, choć dziwili się temu współcześni mu historycy. Nie tak bowiem definiował swoje zadania jako historyk.

Podsumujmy powyższe uwagi. Dziś badacze dziejów historiografii dość rzadko poszukują materiału do swych ustaleń w pracach o charakterze lokalnym. Traktują je jako materiał pozostający echem istniejących lub przemijających nawet tendencji $\mathrm{w}$ historiografii zdominowanej przez standardy akademickie. W sposób często nieuzasadniony kojarzą go z aktywnością antykwarystyczno-zbieracką "miłośniczą" czy też amatorską. Z tego względu badacze "małych ojczyzn” w najlepszym wypadku mogą liczyć na wzmiankę na końcu prac bilansujących osiągnięcia historiografii jakiegoś okresu, przy czym nawet to nie jest regułą.

Tego rodzaju podejście do historiografii lokalnej nie jest uprawnione. Zwrócił na to uwagę ponad ćwierć wieku temu Henryk Samsonowicz, dostrzegając, że praca naukowa nad historią małych jednostek terytorialno-ludnościowych stworzyła praktykę korzystania z lekceważonych przez naukę źródeł i otworzyła nowe perspektywy rozwojowe historio-

${ }^{77}$ A. Czołowski, Lwów w obrazach. Przeszłość i teraźniejszość, [cz. I], Historia Lwowa od założenia - do roku 1600, Lwów 1925; idem, Lwów w obrazach. Przeszłość i teraźniejszość, [cz. II], Historia Lwowa od roku 1600 do roku 1772, Lwów 1927; W dzisiejszym znaczeniu do historii stosowanej odnosi się R. Traba, Historia stosowana jako subdyscyplina akademicka. Konteksty i propozycje, [w:] Historia - dziś..., s. 145-164. 
grafii $^{78}$. Przedstawieni w niniejszym artykule badacze pozostawali w służbie Klio prawie 100 lat temu i z oczywistego względu nie mogą konkurować z dzisiejszymi badaczami regionów, miast czy wsi. W swoich czasach mogli się jednak zaliczyć do grona nowatorów lub przynajmniej do grupy, która przyczyniła się do modernizacji historii.

\section{BIBLIOGRAFIA:}

Bezwiński Z. J., Opisy społeczne zbiorowości terytorialnych Franciszka Bujaka, „Studia i Materiały do Dziejów Nauki Polskiej", seria E, 1965, z. 1.

Budzyński Z., Franciszek Bujak (1875-1953), [w:] Złota księga historiografii lwowskiej XIX i XX wieku, red. J. Maternicki przy współpracy L. Zaszkilniaka, [t. I], Rzeszów 2007, s. $421-440$.

Budzyński Z., Szkoła historii społeczno-gospodarczej Franciszka Bujaka na Uniwersytecie Jana Kazimierza we Lwowie, [w:] Wielokulturowe środowisko historyczne Lwowa w XIX i XX w., t. II, red. J. Maternicki, L. Zaszkilniak, Rzeszów 2004, s. 309-328.

Bujak F., Dział historii gospodarczej, [w:] Muzea regionalne ich cele i zadania, książka zbiorowa, Warszawa 1928, s. 204-217.

Bujak F., Galicja, t. I-II, Lwów 1908-1910.

Bujak F., Limanowa. Miasteczko powiatowe w zachodniej Galicyi. Stan społeczny i gospodarczy, Kraków 1902.

Bujak F., Maszkienice. Wieś powiatu brzeskiego. Stosunki gospodarcze i społeczne, „Rozprawy Akademii Umiejętności. Wydział Historyczno-Filozoficzny", seria 2, t. XVI, Lwów 1901, s. 76-184.

Bujak F., O nauczaniu historii, zwłaszcza w szkołach zawodowych, [w:] Pamiętnik V Powszechnego Zjazdu Historyków Polskich w Warszawie 28 XI-4 XII r., Lwów 1930, s. 625-632.

Bujak F., O pracy naukowej na prowincji nad zagadnieniami gospodarczymi, „Nauka Polska”, t. IV, 1923, s. 237-243.

Bujak F., Uwagi o potrzebach historii gospodarczej, „Nauka Polska. Jej Organizacja i Rozwój”, 1918 , t. I, s. 275-286.

Bujak F., Wieś zachodniogalicyjska u schytku XIX w., "Przegląd Prawa i Administracji”, R. XXIX, 1904, s. 53-111.

Bujak F., Żmiaca. Wieś powiatu limanowskiego. Stosunki gospodarcze i społeczne, Kraków 1903.

Charewiczowa Ł., Dziesięciolecie badań nad dziejami miasta Lwowa, „Kwartalnik Historyczny", R. XLIII, t. II, 1929, s. 115-136.

Charewiczowa Ł., Est-il fonde d'ecrire une histoire specjale de la femmme? Warszawa 1933.

Charewiczowa Ł., Kobieta w dawnej Polsce do okresu rozbiorów, Lwów 1938.

Charewiczowa Ł., Mieszczka lwowska XVI w. Zofia Hanlowa, „Ziemia Czerwieńska” 1935, z. 1, s. 26-66.

Charewiczowa Ł., Z przeszłości Lwowianek, Warszawa 1935.

Chwalba A., O nowy ksztatt historycznych badań regionalnych - uwagi do tekstu Roberta Traby, [w:] O nowy model historycznych badań regionalnych, red. K. A. Makowski, Poznań 2007, s. 89-102.

Czołowski A., Jaworski F., Księga ławnicza miejska 1441-1448, Lwów 1921.

${ }^{78}$ Por. H. Samsonowicz, Historiografia regionalna w Polsce po II wojnie światowej, „Kwartalnik Historyczny", R. XCIV, 1987, z. 1 s. 279-292. 
Czołowski A., Lwów w obrazach. Przeszłość i teraźniejszość, [cz. I], Historia Lwowa od założenia - do roku 1600, Lwów 1925.

Czołowski A., Lwów w obrazach. Przeszłość i teraźniejszość, [cz. II], Historia Lwowa od roku 1600 do roku 1772, Lwów 1927.

Friedberg M., Łucja Charewiczowa (1897-1943), „Kwartalnik Historyczny”, R. LXVI, 19391945, z. 3-4, s. 436-440.

Grabski A.F, Franciszek Bujak i historia gospodarcza (uwagi o metodologicznych pogladach uczonego), „Historyka. Studia Metodologiczne”, t. IX, 1979, s. 101-124.

Hoszowski S., Ceny we Lwowie w latach 1701-1914, Lwów 1934.

Hoszowski S., Ceny we Lwowie w XVI i XVII wieku, przedm. F. Bujak, Lwów 1928.

Hoszowski S., Ekonomiczny rozwój Lwowa w latach 1772-1914, Lwów 1935.

Hoszowski S., Klęski elementarne i ceny w działalności Profesora Franciszka Bujaka, „Sprawozdania Wrocławskiego Towarzystwa Naukowego", 29, 1974, seria A, dodatek.

Inglot S., Franciszek Bujak. Działalność naukowa i pedagogiczna. Referat wygłoszony na posiedzeniu żałobnym Wydziału Historyczno-Filozoficznego dnia 6 maja 1953 roku, „Sprawozdania Wrocławskiego Towarzystwa Naukowego", [t.] 8, 1953, dodatek 3.

Janeczek A., Franciszek Bujak: historyk w nurcie życia, [w:] F. Bujak, Studya nad osadnictwem Małopolski, posł. A. Janeczek, Poznań 2001.

Kałwa D., Historia kobiet versus studia gender, s. 115-126.

Kusiak A., Łucja Charewiczowa - inicjatorka badań nad przeszłościa kobiet polskich, [w:] Kobieta i kultura. Kobiety wśród twórców kultury intelektualnej i artystycznej w dobie rozbiorów i w niepodległym państwie polskim, red. A. Żarnowska, A. Szwarc, t. IV, Warszawa 1996, s. 99-103.

Laszak E., Działalność naukowa Aleksandra Czołowskiego (1865-1944), Łódź 2004.

Madurowicz-Urbańska H., Franciszek Bujak - o nowy ksztatt historii, [w:] F. Bujak, Wybór pism, red. eadem, t. I, Warszawa 1976, s. 12-19.

Madurowicz-Urbańska H., Historia gospodarcza w Polsce jako dyscyplina uniwersytecka. Okres organizacyjny 1905/6-1921/1922. Koncepcja i program, Warszawa, 1974.

Madurowicz-Urbańska H., Łucja Charewiczowa i jej Lwów, [w:] Kraków - Małopolska w Europie Środka. Studia ku czci profesora Jan M. Małeckiego w siedemdziesiata rocznice urodzin, red. K. Broński, J. Purchla, J. Szpak, Kraków 1996.

Madurowicz-Urbańska H., Stan badań nad historią Lwowa w latach 1772-1918, „Rocznik Naukowo-Dydaktyczny" Wyższa Szkoła Pedagogiczna im Komisji Edukacji Narodowej w Krakowie. Prace historyczne XIII, Studia z dziejów Małopolski w XIX i XX wieku, red. L. Mroczko, Kraków 1992, s. 31-43.

Malczewska-Pawelec D., Łucja Charewiczowa (1897-1943), [w:] Złota księga historiografii lwowskiej XIX i XX wieku, t. II, red. J. Maternicki, P. Sierżęga, L. Zaszkilniak, Rzeszów 2014, s. 517-534.

Malczewska-Pawelec D., Łucja Charewiczowa jako badaczka i propagatorka historii regionalnej, „Wieki Stare i Nowe”, w druku.

Mękicki R., Mennica lwowska w latach 1656-1657, Lwów 1932.

Mikułowska C. [Ł. Charewiczowa], Ukraiński ruch kobiecy, Lwów 1937.

Papée F., Historia miasta Lwowa, Lwów 1894.

Pawelec T., Trzy wizje dziejów - F. Bujak, M. Handelsman, J. Rutkowski, [w:] Środowiska historyczne II Rzeczypospolitej, red. J. Maternicki, cz. V, Warszawa 1990, s. 166-186.

Pisulińska J., Lwowskie środowisko historyczne w okresie międzywojennym (1918-1939), Rzeszów 2012.

Rachwał S., Jan Alenpek i jego „Opis miasta Lwowa” z początku XVII w., „Wschód”, t. VI, Lwów 1930. 
Samsonowicz H., Historiografia regionalna w Polsce po II wojnie światowej, „Kwartalnik Historyczny" R. XCIV, 1987, z. 1, s. 279-292.

Sierżęga P., Kazimierz Tyszkowski (1894-1940). Z dziejów nauki polskiej w międzywojennym Lwowie, Rzeszów 2011.

Skoczek J., Dotychczasowy stan badań nad historia Lwowa, „Kwartalnik Historyczny”, R. XXXIX, 1925, nr 2, s. 336-350.

Stępnik A., Historia regionalna i lokalna w Polsce 1918-1939. Badania i popularyzacja, Warszawa 1990.

Stępnik A., Trzy modele historii regionalnej w nauczaniu szkolnym, [w:] Historia. Społeczeństwo. Wychowanie, red. J. Maternicki, M. Hoszowska, P. Sierżęga, Rzeszów 2003, s. 61-70.

Suchumiel J., Łucja Charewiczowa (1897-1943). Życie i dzieło, Częstochowa 2001.

Toczek A., Historycy amatorzy i popularyzatorzy popularni we Lwowie (1860-1918), [w:] Lwów: Miasto-społeczeństwo-kultura, t. V, Ludzie Krakowa, red. K. Karolczak, Kraków 2005, s. 311-321.

Toczek A., Lwowskie środowisko historyczne i jego wkład w kulturę ksiażki i prasy (1860-1918), Kraków 2013.

Toczek A., Środowisko historyków lwowskich w latach 1860-1918, „Prace Komisji Historii Nauki”, Polska Akademia Umiejętności, t. VI, Kraków 2004, s. 123-165.

Toczek A., Zainteresowania twórcze lwowskiego środowiska historycznego okresu autonomii galicyjskiej w zakresie nauk pomocniczych historii, „Annales Universitatis Paedagogicae Cracoviensis", Studia ad Bibliothecarum Scientiam Pertinentia, t. IX, 2011, s. 133-147.

Traba R., Historia stosowana jako subdyscyplina akademicka. Konteksty i propozycje, [w:] Historia - dziś. Teoretyczne problemy wiedzy o przeszłości, red. E. Domańska, R. Stobiecki, T. Wiślicz, Kraków 2014, s. 143-164.

Walawender A., Badanie klęsk elementarnych. Metoda i znaczenie, Lwów 1931.

Walawender A., Kronika klęsk elementarnych w Polsce i krajach sasiednich w latach 1430-1586, Lwów 1932.

Winnicka H., Lwowskie środowisko historyczne 1918-1939, [w:] Środowiska historyczne II Rzeczypospolitej, cz. V, red. J. Maternicki, Warszawa 1990, s. 121-137.

Wnęk J., Rozwój badań nad historia regionalna Galicji, [w:] Galicja 1772-1918. Problemy metodologiczne, stan i potrzeby badań, red. A. Kawalec, W. Wierzbieniec, L. Zaszkilniak, t. 1, Rzeszów 2011, s. 75-99.

Woleński M., Wkład Profesora Franciszka Bujaka do metodologii badań historycznych, "Sprawozdania Wrocławskiego Towarzystwa Naukowego", seria A, 1974, 29, dodatek.

Zima I., Aleksander Czołowski 1865-1944. Luminarz lwowskiej kultury, Gdynia 2011.

\section{ABSTRACT:}

Several hundred historians were active in Lviv between 1869 and 1939. Of these, as many as $10 \%$ specialised in the history of the region, its towns and villages. This group comprised amateurs and professional historians, innovators and traditionalists. Some persons initiated breakthroughs in historiography, contributing to its development, to popularisation of innovative research methods or ways of presenting research outcomes. These developments took place in 1) new socio-economic history, 2) women's history, 3) the history of historiography and 4) public history, and all transcended the canon of research specialisations at the time. The interpretative framework for these activities was worked out by Franciszek Bujak, Łucja Charewiczowa and Aleksander Czołowski. Their research 
should provide a basis to re-evaluate widely-held notions on regional and local historiography; it also underscores the need to modernise the terminology and methodology applied to research into the history of historiography.

Key words: Lviv, local history, new socio-economic history, women's history, the history of historiography

\section{NOTA O AUTORZE:}

Dr hab. Andrzej Stępnik - prof. nadzw. UMCS, kierownik Zakładu Edukacji Historycznej i Dziedzictwa Kulturowego w Instytucie Historii UMCS w Lublinie, specjalizuje się w dydaktyce historii i historii historiografii. Autor wielu prac w tej dziedzinie. 